\title{
Factors Affecting the Sustainability of Microfinance Institutions: A Case of Malawi Microfinance Institutions
}

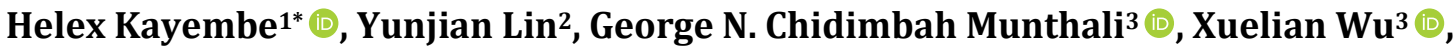 \\ Lazarus Obed Livingstone Banda ${ }^{4,5}\left(\mathbb{D}\right.$, Mastano $\mathrm{N}$. Woleson Dzimbiri6, Colleen Mbughi ${ }^{7}$ \\ ${ }^{1}$ Graduate School of Business, Jiangnan University, Wuxi, China \\ ${ }^{2}$ Jiangnan University Alumni Association, Wuxi, China \\ ${ }^{3}$ School of Economics and Management, Yangtze University, Jingzhou, China \\ ${ }^{4}$ Ministry of Education, Nalikule College of Education, Lilongwe, Malawi \\ ${ }^{5}$ Graduate School of Education, Beijing Institute of Technology, Beijing, China \\ ${ }^{6}$ Department of Geography, Miami University, Oxford, USA \\ ${ }^{7}$ Department of Geography, Chancellor College, University of Malawi, Zomba, Malawi \\ Email: `helexkayembe@yahoo.com, yunjianl@163.com,ndazionaacca@yahoo.com,wuxuelian@yangtze.edu.cn, \\ lazaruslivingstonebanda@gmail.com,dzimbirimastano1@gmail.com,colleenmbughi@gmail.com
}

How to cite this paper: Kayembe, H., Lin, Y. J., Munthali, G. N. C., Wu, X. L., Banda, L. O. L., Dzimbiri, M. N. W., \& Mbughi, C. (2021). Factors Affecting the Sustainability of Microfinance Institutions: A Case of Malawi Microfinance Institutions. Journal of Financial Risk Management, 10, 117-134. https://doi.org/10.4236/jfrm.2021.102007

Received: March 30, 2021

Accepted: May 10, 2021

Published: May 13, 2021

Copyright $\odot 2021$ by author(s) and Scientific Research Publishing Inc. This work is licensed under the Creative Commons Attribution International License (CC BY 4.0).

http://creativecommons.org/licenses/by/4.0/

(c) (i) Open Access

\begin{abstract}
Background: Micro Finance Institutions (MFIs) have been used as a tool for poverty alleviation in many developing economies globally, including Malawi. However, their sustainability in many countries has been dependent solely on loan repayment, donor aid, and subsidies. Aim: This study aimed at investigating the factors that influence the sustainability of MFIs in Malawi. Methods: A cross-sectional survey was conducted from November to December 2020 among the MFIs employees in the central region of Malawi. Convenience and purposive sampling techniques were used to collect data online using a google form sent via social media platforms. Data were analyzed using IBM SPSS software with Statistical significance placed at 0.05 . Results: 120 respondents completed the survey representing $79.3 \%$ response rate, of which $63 \%$ were male. The majority of the respondents fell within the age group of 31 - 40 years, representing 58\%, having attained universities and vocational colleges' education level, representing $32.8 \%$. With an experience of above 16 years, representing $41.2 \%$ of which were branch managers, representing $49.6 \%$. The results of the ordinary least square regression indicated that reporting and loan management system (RLMS) $(\beta=0.200, P=$ $0.021)$, corporate-governance ( $\beta=0.257, P=0.004)$, and commercialization ( $\beta=0.161, P=0.047$ ) were positively significantly influencing the sustainability of MFI. On the other hand, loan design/type ( $\beta=-0.211, P=0.006)$, loan
\end{abstract}


portfolio management $(\beta=-0.179, P=0.050)$ were found to be negatively impacting the MFI. Lastly, variables of over-indebtedness $(\mathrm{B}=0.077, P=$ 0.426 ), loan disbursement ( $\beta=0.121, P=0.104)$ were found statistically insignificant. Conclusion: Our study argues that through commercialization, standardized reporting, and effective loan portfolio management systems, stakeholder-based approach to corporate governance, and favored board independence through scale and cost management is critical to improving MFIs financial sustainability.

\section{Keywords}

Microfinance, Financial Sustainability, Credit Risks, Outreach

\section{Introduction}

Microfinance has been globally accepted as one of the credible tools to alleviate poverty and financial inclusion in developing nations (Chmelíková \& Redlichová, 2020; Sun et al., 2020) Further, it plays an essential role in the provision of "micro" financial services to the financially excluded population, particularly the poor and the informal sector located at the Base of Pyramid (BoP) (Kasenge, 2011). Microfinance refers to the provision of financial services including micro-savings, micro-credit, working capital loans, consumer credit, pensions, micro-insurance, and transfer of payment services and remittances to the indigent population who live below the poverty line surviving on less than $\$ 1.25$. Sataloff, Johns, \& Kost, n.d. reiterated that MFIs could be non-governmental organizations (NGOs), savings and loan cooperatives, credit unions, government banks, commercial banks, or non-bank financial institutions. Likewise, Mutambanadzo, Bhiri, \& Makunike (2013) described microfinance as the supply of financial services to an impoverished population who traditionally lack permission to financial services from conventional MFIs. The World Bank report of 2012 states that more than $75 \%$ of the poor populations globally who earn less than $\$ 2$ per day are unbanked or do not use a formal financial institution due to their lack of stable income and absence of collateral (Kasenge, 2011).

Despite the fact that MFIs are very helpful to the less privileged population, many of these institutions face challenges that affect their operational and productivity (Ousoombangi, 2018). Sustainability is one of the major challenges faced by MFIs (Muhammad, 2010). Sustaining the operational and the administration of the MFIs over a long period of time is becoming a pretty tough, challenging, and general concern for MFIs in developing nations, such as Pakistan as well as Malawi (Zeller \& Sharma, 2000; Muhammad, 2010). Among other factors, non-performing loans by their clients affect the profitability of the MFIs resulting in failure to sustain and maintain themselves over the period of time (Zeller \& Sharma, 2000).

However, apart from the profits they make, most of the MFIs in developing 
and the sub Saharan Africa (SSA) including Malawi get the supports annually worldwide in financial aid, donations, grants, and subsidies from donors, governments(public) and government agencies, Non Governmental Organizations (NGO) and private firms (Brau \& Woller, 2004; Hashemi, 2007; Hermes \& Hudon, 2019). Despite the support towards the MFIs however, evidence on the ground reveals that most of these institutions do not sustain their business operations such as outreach and sustainability goals (Dannroth, n.d.). As such most of these institutions have lost their business capital and are ceasing to operate. From the available literature, reasons that have been reported to influence the sustainability of MFIs in Malawi seem positively and negatively to be speculative and myopic since they do not reflect a holistic picture of the situation on the ground (MFTransparency, 2011). Given the absence of comprehensive understanding of critical issues or factors that challenge operations of MFIs and the failure of the strategies that have been put in place to sustain their operations this paper attempted to carry out a comprehensive study to address the existing knowledge gap and provide insights on its significance on how to achieve.

The study aimed at exploring the key factors that affect the sustainability of MFIs in Malawi. The study sought to address the main goal by answering the following research questions: 1) What are the factors that influence the sustainability of microfinance institutions in Malawi? 2) What are the effective strategies for achieving microfinance sustainability in Malawi? Our study contributes to the literature gap as well as informing policy makers involved in MFI and those associated with fighting against poverty in developing countries.

\section{Methodology}

\subsection{Research Variables}

\subsubsection{Dependent Variable}

This study regards sustainability (Loan Performance) of MFIs as the dependent variable (see Figure 1) using a 5 Likert scale question ranging from Strongly Disagree to Strongly Agree.

\subsubsection{Independent Variable}

In this study, the independent variables were the standardized reporting and loan performance monitoring system, loan disbursement, loan design/type, loan portfolio management, corporate governance, commercialization, and over-indebtedness (see Figure 1). A 5 Likert scale question also measured these variables ranging from Strongly Disagree to Strongly Agree.

\subsubsection{Control Variables}

To start with the demographic characteristics process on the factors affecting the sustainability of microfinance institutions-data were collected on gender, age group, company operations, working experience, education, and positions. 


\subsection{Study Design and Setting}

This study was conducted in Lilongwe, Dedza, Ntcheu, Mchinji, Dowa, Kasungu, Salima, Nkhotakota, and Ntchisi districts situated in the central religion of Malawi (Figure 2). Malawi is a landlocked country located in the southern part of Africa bordering Zambia to the west, Mozambique to the south-west, and Tanzania to the north (Figure 2). The vast majority of the country's population depends on agriculture and most of these live under the poverty line whose income usually depend on loans for farming and conducting small scale business (Munthali \& Wu, 2020b, 2020a). The study adopted a cross-sectional survey design in which data was collected using a Google form that was sent online via social media platforms like WhatsApp, Facebook, and email on the first week of September 2020 to 31st December 2020. We targeted only the Microfinance employees in the Central region of Malawi.

\subsection{Population and Sampling}

We purposively selected the central region part of Malawi to collect data due to the fact that the region has the highest number of MFI in Malawi. This provided us an opportunity to collect more data from a larger population. Further, some researchers have strong connections with people in the central region, and this made the process of data collection much easier. There are a total of 32 microfinance institutions in Malawi which operate in all regions according (Registrar, 2019). Furthermore, with the existing COVID-19 restrictions, purposive and convenience sampling through online modes have been proved to be more effective ways of sampling and collecting data during this period (Song, Liu, He, Cai, $\& \mathrm{Xu}, 2020)$. With this limited population, we targeted all the institutions knowing that these institutions do not have many employees as respondents in this study.

Independent Variable Dependent Variable

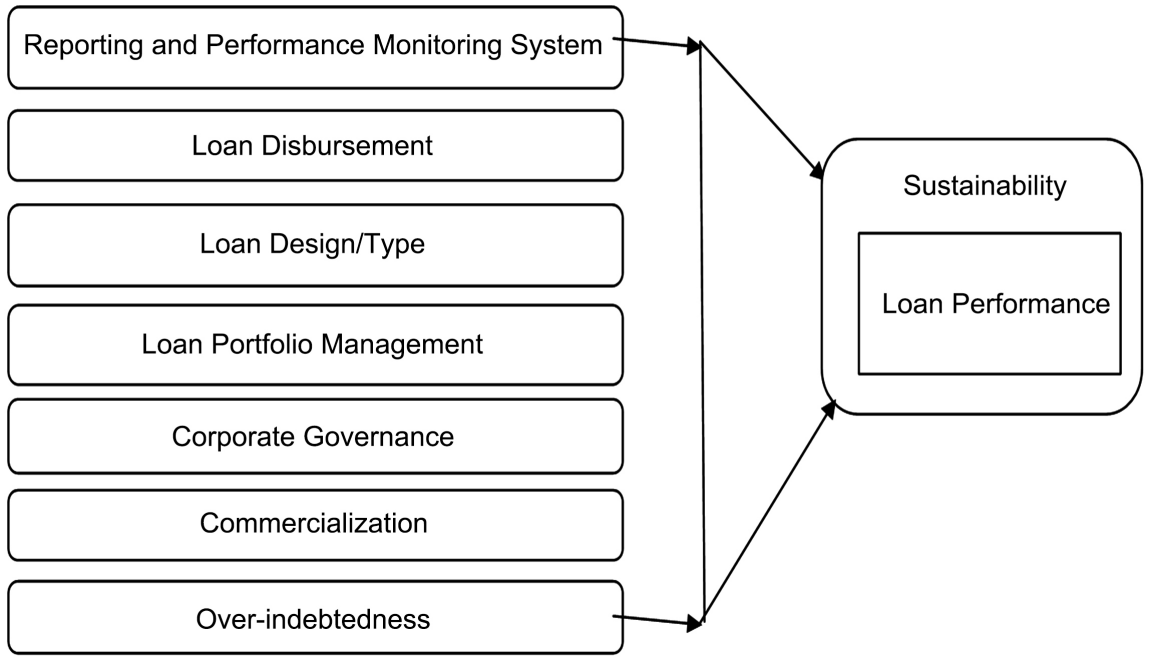

Figure 1. Relationship between variables. Source: Researcher (2021). 


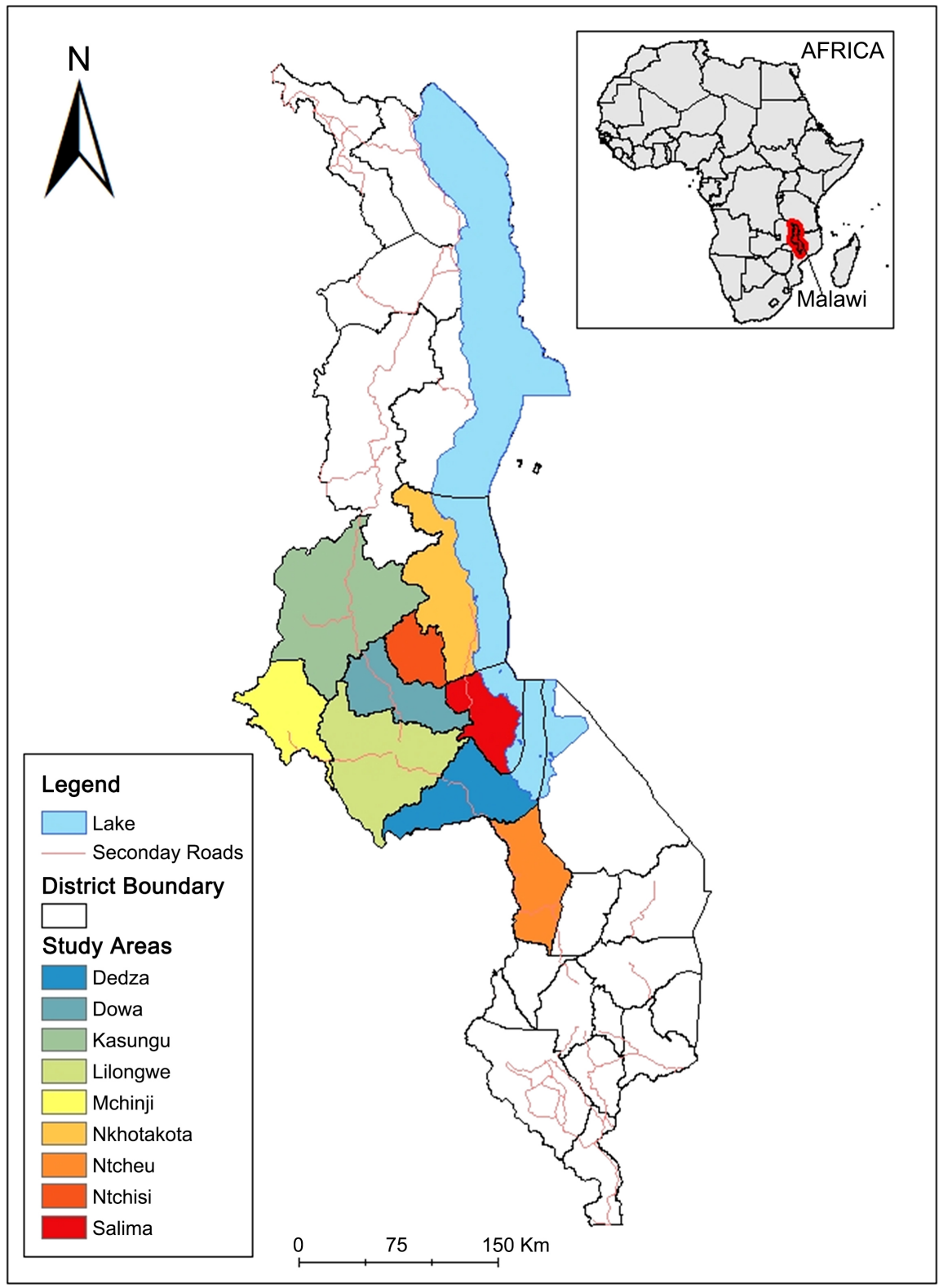

Figure 2. Location of the study areas in central region of Malawi. Source: Authors, 2021.

\subsection{Data Analysis}

IBM SPPS version 25 was used to analyze the data. Descriptive statistics were presented in the form of Frequencies, Mean, and Standard Deviation. Frequency tables were generated, and further performed regression analysis with p-value put at 0.05 as significance so as to find the study model's predictability. An ordinary least square model was used to find factors that affect the sustainability of MFI. The model was developed as.

$$
\mathrm{Y}=\mathrm{F}(\mathrm{X} 1, \mathrm{X} 2, \mathrm{X} 3, \mathrm{X} 4, \mathrm{X} 5, \mathrm{X} 6, \mathrm{X} 7, \cdots, e i)
$$

where $\mathrm{Y}=$ Loan performance was the dependent variable, and $\mathrm{X} 1, \mathrm{X} 2, \mathrm{X} 3, \mathrm{X} 4, \cdots$, $=$ were the independent variables. 


\subsection{Consent and Clearance}

Before the questionnaire was sent, an official communication was granted from the president of the association of microfinance in Malawi, who facilitated the questionnaire's sharing. Respondents were informed in advance that this study was voluntary and had full rights of withdrawal at any time. Informed consent was collected from all the participants before filling the form.

\subsection{Validation and Reliability}

The instrument was sent to other experts in the field who commented on its viability, collecting the essential information, and all the comments were taken into consideration before the final data collection. Furthermore, we pretested the instrument by sending it to 10 people who filled it, and we tried to check the errors.

\section{Results}

\subsection{Social Demographic Characteristics}

Out of 150 targeted members, 120 participated in the survey representing 79.3\% response rate. The social demographic characteristics of the respondents are presented in Table 1. The results indicate that the majority of the respondents were male, representing $63 \%(\mathrm{n}=75)$ while the female was $37 \%(\mathrm{n}=44)$. In terms of age, the majority fell within the age-group category of 31 - 40 years $58 \%$ $(n=69)$, followed by those within $21-30$ years $35.3 \%(n=42)$. Furthermore, on the number of years the companies have been in operation, the results indicated that the majority have been in operation more than 16 years, representing $41.2 \%$ $(\mathrm{n}=49)$, followed by those in operation between $11-15$ years representing $29.4 \%(n=35)$ and $6-10$ years representing $24.4 \%(n=29)$. On working experience, the result reveals that the majority of the respondents had been working with microfinance institutions between the range of $6-10$ years, representing $43.7 \%(\mathrm{n}=52)$, followed by $11-20$ years and $0-5$ years, both representing $20.2 \%(n=24)$, and finally those above 21 years representing $16 \%(n=19)$. In terms of education, the study shows that the majority of the respondents, $32.8 \%$ $(\mathrm{n}=39)$, have both vocational certificates and bachelor's degree obtained from different colleges and universities, followed by those having MSCE 18.5\% ( $\mathrm{n}=$ 22) and lastly, those having master's degree $16 \%(\mathrm{n}=19)$. Most of these were branch managers $49.6 \%(n=59)$, and by loan officers $25.2 \%(n=30)$.

\subsection{Econometric Model Results}

We conducted a linear regression analysis to determine the impact of variables such as 1) social demographic (gender, age, experience, operations, education, and positions); as well as 2) independent variables like the reporting and loan performance monitoring system, loan disbursement, loan design/type, loan portfolio management, corporate governance, commercialization, and over-indebtedness on the dependent variable sustainability (loan performance) of MFIs. Table 2 shows the results of the analysis. 
Table 1. Social demographic characteristics $(\mathrm{N}=119)$.

\begin{tabular}{|c|c|c|c|}
\hline Variable & Category & $\mathrm{F}$ & Percentage \\
\hline \multirow{2}{*}{ Gender } & Female & 44 & 37 \\
\hline & Male & 75 & 63 \\
\hline \multirow{3}{*}{ Age } & $21-30$ & 42 & 35.3 \\
\hline & $31-40$ & 69 & 58 \\
\hline & $41+$ & 8 & 6.7 \\
\hline \multirow{4}{*}{ Experience } & $0-5$ & 6 & 5 \\
\hline & $06-10$ & 29 & 24.4 \\
\hline & $11-15$ & 35 & 29.4 \\
\hline & $16+$ & 49 & 41.2 \\
\hline \multirow{4}{*}{ Operation } & $0-5$ & 24 & 20.2 \\
\hline & $06-10$ & 52 & 43.7 \\
\hline & $11-20$ & 24 & 20.2 \\
\hline & $21+$ & 19 & 16 \\
\hline \multirow{4}{*}{ Education } & MSCE & 22 & 18.5 \\
\hline & Vocational & 39 & 32.8 \\
\hline & $\mathrm{BD}$ & 39 & 32.8 \\
\hline & Master's degree+ & 19 & 16 \\
\hline \multirow{6}{*}{ Position } & Loan officer & 30 & 25.2 \\
\hline & Supervisor & 18 & 15.1 \\
\hline & Branch Manager & 59 & 49.6 \\
\hline & ISO & 4 & 3.4 \\
\hline & ACC & 6 & 5 \\
\hline & Others not here & 2 & 1.7 \\
\hline
\end{tabular}

Source: Field study, 2021 Note: Min = Minimum, $\mathrm{SD}=$ Standard Deviation, $\mathrm{ISO}=$ Information System Officer, $\mathrm{ACC}=$ Accountant, $8=$, MSCE $=$ Malawi School Certificate of Education, $\mathrm{BD}=$ Bachelor's Degree

To establish the relationship between the independent and dependent variables and their significance, statistical analyses relied on the linear regression analysis's p-value to demonstrate the relationship as indicated in Table 2. The statistical significance level is often expressed as a p-value between 0 and 1: the smaller the p-value, the more substantial the evidence that you should reject the null hypothesis. A p-value higher than $0.05(>0.05)$ is not statistically significant and indicates strong evidence for the null hypothesis (McLeod, 2019). On the part of the social demographic variable (gender, age, experience, operations, education, and positions), the results demonstrated that none of the social demographic variables for the sustainability (loan performance) items have a statistically significant influence on the sustainability of microfinance institutions in Malawi. 
Table 2. Regression analysis results.

\begin{tabular}{|c|c|c|c|c|c|c|}
\hline \multirow{2}{*}{ Variables } & \multicolumn{2}{|c|}{$\begin{array}{l}\text { Unstandardized } \\
\text { Coefficients }\end{array}$} & \multirow{2}{*}{$\mathbf{t}$} & \multirow{2}{*}{ P-Values } & \multicolumn{2}{|c|}{$\begin{array}{c}\text { Collinearity } \\
\text { Statistics }\end{array}$} \\
\hline & B & Std. Error & & & Tolerance & VIP \\
\hline (Constant) & 2.032 & 0.917 & 2.214 & 0.029 & & \\
\hline Gender & -0.039 & 0.117 & -0.331 & 0.741 & 0.766 & 1.306 \\
\hline Age & -0.019 & 0.110 & -0.172 & 0.864 & 0.590 & 1.696 \\
\hline Experience & 0.014 & 0.059 & 0.243 & 0.808 & 0.816 & 1.225 \\
\hline Working & 0.009 & 0.060 & 0.145 & 0.885 & 0.713 & 1.403 \\
\hline Education & 0.072 & 0.054 & 1.326 & 0.188 & 0.877 & 1.140 \\
\hline RLM System & 0.209 & 0.084 & 2.497 & $0.014^{*}$ & 0.765 & 1.307 \\
\hline Loan Disbursement & 0.131 & 0.073 & 1.787 & 0.077 & 0.883 & 1.133 \\
\hline Loan Design/Type & -0.194 & 0.073 & -2.669 & $0.009 * *$ & 0.814 & 1.229 \\
\hline Loan Port Management & -0.175 & 0.088 & -1.989 & $0.049^{*}$ & 0.558 & 1.791 \\
\hline Over Indebtedness & 0.081 & 0.091 & 0.889 & 0.376 & 0.744 & 1.345 \\
\hline Corporate Governance & 0.246 & 0.077 & 3.182 & $0.002^{* *}$ & 0.946 & 1.057 \\
\hline Commercialization & 0.197 & 0.073 & 2.704 & $0.008^{* *}$ & 0.862 & 1.161 \\
\hline F value & 7.574 & & & & & \\
\hline $\mathrm{R}^{2}$ & 0.462 & & & & & \\
\hline Adjusted $\mathrm{R}^{2}$ & 0.401 & & & & & \\
\hline Durbin Walt & 1.807 & & & & & \\
\hline $\mathrm{DF}$ & $(12,106)$ & & & & & \\
\hline Number & 119 & & & & & \\
\hline
\end{tabular}

Note: RLMS $=$ Reporting and Loan Management System, ${ }^{*}$ statistic significant at 0.05 level, ${ }^{*}$ statistic significant at 0.001 level.

On the influence of the independent variables on the sustainability of MFIs, our results reveal that Reporting and Loan Monitoring Systems (RLMS) significantly influence the sustainability of microfinance institutions in Malawi at $\beta=$ $0.200(P=0.021, P<0.01)$. This means that an increase in standard deviation by one in reporting and loan monitoring would cause a rise in sustainability (loan performance) of MFIs by 0.200 . In continuation, the variables of corporate governance and commercialization indicated a significant favorable influence with $\beta=0.257(P=0.004, P<0.01)$ and $\beta=0.161(P=0.047, P<0.05)$, and this entails that a rise in standard deviation by one in commercialization and loan portfolio management would cause a rise in sustainability (loan performance) of MFIs by 0.257 and 0.179 , respectively. 
Lastly, the result indicates that loan design type and loan portfolio management had a negative significance influence on the microfinance influence with $\beta$ $=-0.211(P=0.006, P<0.01)$, and $\beta=-0.179(P=0.05, P \leq 0.05)$ respectively. On the other hand, we did not find any significant influence on loan disbursement and over-indebtedness with $\beta=0.121$ ( $P=0.0104, P>0.05)$, and $\beta=0.077$ $(P=0.426, P>0.05)$ respectively.

\section{Discussion}

Gender equality in the workplace had an impact on both employees and the organization. Organizations that promote gender diversity perform better than the rest since they can achieve high retention rates of employees, thereby reducing financial costs towards new employees such as advertisement, recruitment, training, administrative activities, termination pay, and on boarding costs, hence enhancing financial sustainability. A gender gap report of 2013 revealed that, on average, over $96 \%$ of the gap affects health outcomes, $93 \%$ of the gap affects educational attainment, $60 \%$ affects economic participation and $21 \%$ of the gap affects political empowerment (Source...). As per our findings of this study, the majority with a significant variance of the Malawi Microfinance Institutions employees were male, which could be observed to have a gender imbalance. From microfinance perspectives, women employees make up the majority of much more loyal, skilled and add value to the organization performance than male employees. Our study agrees with the study conducted in Sri Lanka, which discovered a significant negative association between female employees and company performance (Wellalage \& Locke, 2013). On the contrary, other studies reveal that board diversity with a higher percentage of women employees increases MFI performance (Bassem, 2010).

Further, the results show that most employees in Malawi MFIs are adults and highly mature with a consideration level of age above 31 years of age. Having matured and adults' workers in an organization could be argued to increase job performance through the experience they may have attained henceforth improve financial sustainability. Besides, adult employees could help mentor, help younger employees with their work, and keep a positive work attitude. However, our results differ from other studies that indicated that age is significantly positively related to an organization's performance, as we did not find it statistically significant with performance. In continuation, it is of good interest that this research's findings have demonstrated low employee turnover in many microfinance institutions as employees can stay for more than $6-10$ years at one institution. This means that many employees who participated in this research are of high vast experience in MFIs. This is a good indication in terms of the sustainability of Microfinance as literature shows that recruitment of new staff is expensive because there is an attachment of recruitment costs and training costs that affect the company's profitability. The experience, on the other hand, has also been appraised to result in efficiency and increase productivity, thus influencing 
the sustainability of the institution as it was found that the higher the credit staff's experience, the higher the loan collection (Umamuefula, Onyeagocha, Angus, Dixie, \& Chukwuemeka, 2012).

Our findings suggest that many Microfinance institutions in Malawi are mainly in operations for many years, increasing their productivity and outreach. This could be explained as the results of political and economic stability that Malawi has been enjoying for many years and other internal factors like profitability that they are making. Concurring with other researchers such as Seo, Bartunek, \& Barrett (2010) who found that company growth beyond the optimal degrees can encounter negative impact performance. Likewise, Bassem (2010) found that there is a negative correlation among size/age and MFIs efficiency while McKibbin \& Sidorenko (2006) discovered that smaller MFIs were more sustainable in terms of making profits than larger ones demonstrating the negative influence of age and size on the performance of MFIs. It is not surprising that at least all the employees in Microfinance institutions and attained higher education as there is competition on employment in the developing economies, including Malawi where the majority of the people are well educated but unemployed (Dixit, Gupta, Singh, \& Gupta, 2011).

The success of any microfinance institution's sustainability depends not only on managing the costs but also on developing a standardized reporting and performance monitoring system. Developing standardized reporting and performance monitoring systems has proven to be essential for the success and sustainability of MFIs over time. This study's findings reveal a strong positive correlation between standardized reporting and performance monitoring system and MFIs sustainability/loan performance. It is believed that MFIs, which have standardized reporting and performance monitoring systems, can determine operational risks like fraud cases and quickly tracing the quality of the loan performance. Moreover, it is suggested by other researchers that an inadequate information system exposes microfinance institutions to fraudulent activities. So, MFIs must consider employing standardized reporting and performance monitoring systems for their success.

Furthermore, we suggested that MFIs implement adequate supervision and implement appropriate management strategies to mitigate portfolio risks and train clients to run their businesses successfully. Our findings support the study conducted by Muhammad, 2010 and Thesis, 2008 who found that standardized reporting and performance monitoring systems positively influence MFIs sustainability. They added that lack of standardized reporting and performance monitoring systems negatively impact outreach, loan collection, breadth, and the financial sustainability performance of MFIs.

The study's findings have revealed a positive relationship between loan disbursement and the sustainability of MFIs. However, the independent variable has no direct impact on the sustainability of microfinance institutions. Even though loan disbursement has no direct influence on the institution's loan per- 
formance, we suggest that timely processing and disbursement of loans to borrowers could enhance MFIs performance and help them be competitive in the marketplace. We also argue that late disbursement would increase loan defaults hence negatively impact the profitability of the institution. Timely loan disbursement could motivate employees and clients hence build long institutionclient's relationships. The study findings support the findings by Karama (2007).

On the contrary, our study findings differ from the findings by Wangechi (2009) on factors influencing microfinance institutions' sustainability in Kenya. In her study, it was found that disbursement factors had the most significant and positive influence on the sustainability of microfinance institutions in Kenya. The discrepancies could be explained with the main economic and differentiating political factors between these two economies and the study setups.

From the available literature, it is evident that a better understanding of loan repayment attitude of clients can enhance to the development of microfinance performance (Mirpourian, Caragliu, Di Maio, Landoni, \& Rusinà, 2016). Scholars argue that designing suitable loan product/type in terms of repayment frequency, interest rate loan sizes, lending methodology applied, loan security, and repayment period could help MFIs to attract, retain, reduce client's dropout rate and loan default, thus increases loan repayment performance and financial sustainability. It is believed that lending methodology like (group lending) helps the MFIs to achieve financial sustainability as group members do communicate and monitor one another during and after repayment of the loan (Jia, Cull, Guo, \& Ma, 2016).

Designing an effective loan repayment schedule increases the $96 \%$ on-time repayment rate and high client retention rate, thus positively enhancing sustainability (Alam \& Getubig, 2010). This study's findings concurred with the researchers that, indeed, there is a powerful positive significant correlation influence between loan design/type and the sustainability of MFIs. Furthermore, our results support the findings from Ayayi, n.d.; Sekabira, Economics, Economics, \& Sciences (2013) which argued that affordable interest rates charged to borrowers could help MFIs be financially sustainable. Furthermore, our results agree with the findings from Michael (Adusei, 2021) which suggests that interest rate increase the social performance (both the breadth and depth of outreach) of MFI. In conclusion, our study suggests that MFIs should implement effective loan design/type in terms of sizes and interest rates suitable for indigent clients. Providing bigger loans and charging high-interest rates to clients to attain high profits could contribute to high loan default and over-indebtedness, negatively impacting MFIs sustainability. This view is in support of study findings by (Wasiaturrahma, Ajija, Sukmana, Sari, \& Hudaifah, 2020) that bigger loan size and non-performing loan have a negative influence on MFIs outreach.

Many studies state that loan portfolio management is a critical asset and the profoundly important backbone of institutional revenue if it is managed well. This translates that there is a strong positive relationship between loan portfolio 
quality and revenue-MFI performance (Afrifa, Gyapong, \& Zalata, 2019). Their findings are in line with our results, which have revealed a strong positive, statistically significant difference between loan portfolio management and the sustainability of MFIs. Furthermore, our results suggest implementing an effective loan portfolio management system, loan assessment, adequate supervision by loan officers, effective loan collection strategies, and adequate collateral as techniques that could help MFIs lower bad loans, thus increasing the loan portfolio's quality, profitability, and financial sustainability. Our results findings are in line with the study by Kosgei, Cheboi, \& Kemboi (2019), which indicated that loan portfolio quality management positively influences the MFIs financial sustainability. Our study argues that failure in managing portfolio performance of MFIs results from not implementing effective lending regulations and enough loan management principles. We believe that poor loan portfolio management creates room for excessive risk concentration and fraudulent malpractice. Thus, makes MFIs remain unsustainable.

On the part of Over-indebtedness, our study findings demonstrated a positive relationship between over-indebtedness and loan performance/sustainability of MFIs in Malawi. The results revealed that over-indebtedness has a statistically insignificant positive effect on MFIs sustainability in Malawi. This translates to the variable impacts negatively the sustainability of MFIs. This result is in line with study findings by (Schicks, 2014). We critically observed that over-indebtedness increases in MFIs due to a lack of "Asymmetric information" of clients. This problem increases loan repayment default rate hence negatively influences financial sustainability level and social impact. This result is in line with what Afonso (2014) found. We argued that over-indebtedness could be minimized by employing group lending methodology to help MFIs have asymmetric information of the borrowers before rendering loans to the group. Besides, the study suggests that MFIs should make sure that women borrowers are recruited more than men clients to avoid over-indebtedness of loans. This view is in line with the study findings from (Boehe \& Barin Cruz, 2013) which argued that female borrowers in MFIs improve the MFI's performance through enhanced debt repayment, especially under adverse cognitive and regulatory institutional situations. This translates that female engagement has a positive significant influence on MFI performance because they are more trustworthy and have greater social influence (Aggarwal, Goodell, \& Selleck, 2015).

In terms of corporate governance influence on MFIs sustainability, our results indicated a strong positive and statistically significant impact association between good corporate governance and MFI sustainability in Malawi. This explains that the variable is one of the key influencing factors to the Malawian microfinance sustainability/loan performance campaign. Furthermore, our result translates that a broader stakeholder-based approach to corporate governance and favored board independence would help microfinance institutions to manage the trade-off between outreach and financial self-sufficiency. This could help 
to increase transparency and improve their financial sustainability. This result is in line with study by (Iqbal, Nawaz, \& Ehsan, 2019) which argued that good corporate governance is considered as one of the key influential determinants building block of success for microfinance institutions (MFIs) as it supports them in achieving their social and financial sustainability and goals. Furthermore, our study result is in line with the results by Type \& Felix (2021) who found a significant positive relationship between corporate governance and the financial sustainability of MFIs. Their results also demonstrate that good corporate governance had a statistically significant influence on loan performance. Besides, they argued that MFIs performance could be improved when the institutional board members were informed by an internal auditor and had local directors led by the woman Chief Executive Officer (CEO). Our results suggest that women's involvement in high positions may increase institutional incomes, slower operational risks, and suit within an agency theory model. The above-stated view is in line with what Adams \& Ferreira (2009) argued that putting women in higher positions tends to significantly influence the outreach and financial performance of MFIs. This supports our argument that MFIs should install governance systems to alleviate agency costs and other losses through malpractices by other stakeholders.

Microfinance institutions experience several challenges while providing financial services to the outreach and covering their costs. Literature suggests that commercialization could help microfinance institutions lower delinquency rates henceforth achieve sustainability. Our study findings demonstrate a strong positive and statistically significant association impact between commercialization and the sustainability of MFIs in Malawi. This result explains that the variable is one of the key influencing factors to Malawian microfinance sustainability/loan performance. The results confirmed findings of a study by Christensen (2000) and Hamada (2010) which revealed that 1) commercialization positively influences the growth of MFIs like profitability, competition, and regulation; 2) commercialization provides unrestricted access to market-based funds and the potentiality of mobilizing funds, thus enhance profitability; 3) commercialization increase credit expansion and build assertive outreach, thus help MFIs to achieve its financial sustainability. On contrary note, our results differ with the views of (Cozarenco \& Szafarz, 2020), who contended that Microfinance mission drift to commercialization can increase unemployment and dependency on social safety nets among disadvantaged population targeted by MFIs such as like the unemployed, women, and migrants seeking financial empowerment through self-employment.

The study also shows that MFIs with a focus on commercialization can be financially stable, and this can increase its breadth. Besides, we noted that commercialization would help MFIs not to depend much on debts, aid, grants, and donations. Thus, we argue that debts, aid, grants, and donations are negatively related to the competitive, efficient, sustainable operations and financial sustai- 
nability of MFIs. This view is in line with the ideas of Bogan (2012) and Sekabira et al. (2013). Despite that commercialization has significant positive impacts on the sustainability of the MFIs, it somehow, bring about a principal-agent dilemma. This comes when the shareholders can delegate responsibilities to MFIs to implement their policies. However, institutions in pursuit of profits can sometimes undermine the principal's diplomatic objectives and goals, rendering initiatives that behave in an orderly manner fruitless because MFIs may focus on profit maximization, hence, lack of asymmetric information rises. Information asymmetries apply whenever the principal and the agent do not have the same information simultaneously. Because of self-interest, they will not be willing to share all the information all of the time. Therefore, the following hidden characteristics, information, and intention information asymmetries apply to acting parties. This type of information asymmetries generates risks such as adverse selection, moral hazard, and hold-up, and sometimes the chances for microfinance institutions to fall are high. For effective implementation of microfinance commercialization, there is a need for total cooperation, transparency, accountability, and trust between MFI shareholders, board of directors, Chief Executive Officers, managers, and loan officers, including clients, to avoid conflict of interest, which can hinder the MFIs sustainability.

\section{Recommendations}

Based on the findings, the study recommends that 1) MFIs in Malawi should consider putting in place necessary policy and regulatory frameworks that could be conducive for the smooth and effective operations of their operations; 2) Microfinance institutions should improve methodology that will attract and increase the number of clients so that they can enhance the funding; 3) MFIs should put effective measures so that more borrowers can repay up their loans without default. Such effective measures include putting in place appropriate management techniques to alleviate portfolio risks, frequently review credit risk methodologies used, and increase loan monitoring framework; portfolio management techniques of the MFIs should concentrate more on internal causes of delinquency, offer clients with financial education management training, this will help clients to build successful enterprises. MFIs should lay clear legal steps to help recover the loans and use credit reference bureau to address loan defaulters' problem; 4) Reporting requirements for microfinance institutions should be standardized to enhance institutional comparison with other financial institutions. Microfinance institutions should have information systems that produce actual, apparent, accurate, timely, and relevant information for top management decision making and also focus on well-developed loan tracking and financial reporting systems, reporting on values of accumulated costs and income both on a profit-center basis; 5) The government should look into regulatory factors which hinder the sustainability of microfinance institutions and come up with alternative solutions. This will help the institution achieve its primary objective 
of alleviating poverty in poor rural areas, and the Management of microfinance institutions should conduct regular audits. This will help to monitor and correct malpractices.

\section{Conclusion}

This study investigates and establishes the key factors that influence the sustainability of MFIs in Malawi. Therefore, the study addressed the following research questions; what factors that influence the sustainability of microfinance institutions in Malawi? What are factors that can negatively affect or influence the sustainability of microfinance institutions in Malawi? What are the effective strategies for achieving microfinance sustainability in Malawi? From the analysis of our data as discussed, there is strong evidence to suggest that these were the key findings to our research questions and objectives: The study established that the sustainability of microfinance institutions' operation in Malawi are statistically significant and positively influenced by three key factors, namely, reporting and performance monitoring system; corporate governance and commercialization. On the other hand, the results have established that the sustainability of MFIs in Malawi is statistically significant and negatively impacted by loan design and loan portfolio management.

The study also discussed the factors that hinder the sustainability of MFIs in Malawi. The study findings demonstrated that loan disbursement and over-indebtedness negatively impact its operation and organizational sustainability. On the best practices of achieving MFI sustainability in Malawi, our study argued through commercialization, standardized reporting, effective loan portfolio management systems, stakeholder-based approach to corporate governance, and favored board independence, through scale and cost management, would improve its financial sustainability.

\subsection{Limitation of the Study}

Two significant limitations were experienced in conducting the present study. Firstly, while adequate information was obtained from respondents, access to some critical information was not possible since some respondents could not disclose all information to researchers for fear of breach of institutional rules and regulations. Other limitations about COVID-19 pandemic preventative procedures disrupted the data collection process. The fact that the study did not receive any funding also contributed to a limitation as many were expecting something in return after filling the forms.

\subsection{Further Research}

Further research need to be done on how best the government would regulate micro financing institutions to the advantage of those investing in these institutions and the clients without inconveniencing the mainstream banking and micro financing institutions in the country. 


\section{Acknowledgements}

We want to thank the Management of Jiangnan University School of Business and Yangtze University School of Economics and Management for the continual support they render to us. We thank Mr. Henry Maduka for accepting our request to facilitate the study site and Associate Professor Kingsley Masamba for data collection and helping in reviewing the paper.

\section{Conflicts of Interest}

The authors declare no conflicts of interest regarding the publication of this paper.

\section{References}

Adams, R. B., \& Ferreira, D. (2009). Women in the Boardroom and Their Impact on Governance and Performance. Journal of Financial Economics, 94, 291-309. https://doi.org/10.1016/j.jfineco.2008.10.007

Adusei, M. (2021). Interest Rate and the Social Performance of Microfinance Institutions. The Quarterly Review of Economics and Finance, 80, 21-30. https://doi.org/10.1016/j.qref.2021.01.009

Afonso, J. S. (2014). Loan Officers and Clients' Over-Indebtedness Prevention-The Case of Banco Adopem (pp. 43-76).

Afrifa, G. A., Gyapong, E., \& Zalata, A. M. (2019). Buffer Capital, Loan Portfolio Quality and the Performance of Microfinance Institutions: A Global Analysis. Journal of Financial Stability, 44, 100691. https://doi.org/10.1016/j.jfs.2019.100691

Aggarwal, R., Goodell, J. W., \& Selleck, L. J. (2015). Lending to Women in Microfinance: Role of Social Trust. International Business Review, 24, 55-65. https://doi.org/10.1016/j.ibusrev.2014.05.008

Alam, M. N., \& Getubig, D. M. (2010). Guidelines for Establishing and Operating Grameen-Style Microcredit Programs Based on the Practices of Grameen Bank and the Experiences of Grameen Trust and Grameen Foundation Partners. Grameen Foundation, Grameen Trust.

Ayayi, A. G. (n.d.). What Drives Microfinance Institution's Financial Sustainability.

Bassem, B. S. (2010). Governance and Performance of Microfinance Institutions in Mediterranean Countries. Journal of Business Economics and Management, 10, 31-43.

Boehe, D. M., \& Barin Cruz, L. (2013). Gender and Microfinance Performance: Why Does the Institutional Context Matter? World Development, 47, 121-135. https://doi.org/10.1016/j.worlddev.2013.02.012

Bogan, V. L. (2012). Capital Structure and Sustainability: An Empirical Study of Microfinance Institutions. The Review of Economics and Statistics, 94, 1045-1058.

https://doi.org/10.1162/REST_a_00223

Brau, J. C., \& Woller, G. M. (2004). Microfinance: A Comprehensive Review of the Existing Literature. Journal of Entrepreneurial Finance and Business Ventures, 9, 1-26.

Chmelíková, G., \& Redlichová, R. (2020). Is There a Link between Financial Exclusion and Over-Indebtedness? Evidence from Czech Peripheral Municipalities. Journal of Rural Studies, 78, 457-466. https://doi.org/10.1016/j.jrurstud.2020.07.010

Christensen, C. (2000). The New Policy Environment for Food Aid: The Challenge of Sub-Saharan Africa. Food Policy, 25, 255-268.

https://doi.org/10.1016/S0306-9192(00)00005-1 
Cozarenco, A., \& Szafarz, A. (2020). The Regulation of Prosocial Lending: Are Loan Ceilings Effective? Journal of Banking and Finance, 121, 105979.

https://doi.org/10.1016/j.jbankfin.2020.105979

Dannroth, S. (n.d.). On the Performance of Microfinance Institutions: Why African MFIs Lag Behind? Berlin: Humboldt University School of Business Economics, Institute of Public Economics.

Dixit, J. K., Gupta, S. K., Singh, P., \& Gupta, H. (2011). Educated Unemployed: A Challenge before Sustainable Education. The International Conference on Sustainable Manufacturing: Issues, Trends and Practices, Pilani, Rajasthan, May 2014, 150-155.

Hamada, M. (2010). Commercialization of Microfinance in Indonesia: The Shortage of Funds and the Linkage Program. Developing Economies, 48, 156-176. https://doi.org/10.1111/j.1746-1049.2010.00102.x

Hashemi, S. (2007). Beyond Good Intentions: Measuring the Social. Cgap, 41. http://www.cgap.org/publications/beyond-good-intentions

Hermes, N., \& Hudon, M. (2019). Chapter 10. Determinants of the Performance of Microfinance Institutions: A Systematic Review. In Contemporary Topics in Finance: A Collection of Literature Surveys (pp. 297-330). Hoboken, NJ: Wiley. https://doi.org/10.1002/9781119565178.ch10

Iqbal, S., Nawaz, A., \& Ehsan, S. (2019). Financial Performance and Corporate Governance in Microfinance: Evidence from Asia. Journal of Asian Economics, 60, 1-13. https://doi.org/10.1016/j.asieco.2018.10.002

Jia, X., Cull, R., Guo, P., \& Ma, T. (2016). Commercialization and Mission Drift: Evidence from a Large Chinese Microfinance Institution. China Economic Review, 40, 17-32. https://doi.org/10.1016/j.chieco.2016.05.007

Karama, G. B. (2007). Examining Factors Promoting Microfinance Clients Dropout. 133.

Kasenge, E. (2011). Achieving Sustainability While Delivering on the Social Impact: Challenges Facing Microfinance Institutions.

Kosgei, S., Cheboi, J., \& Kemboi, A. (2019). Does Portfolio Quality Influence Financial Sustainability? A Case of Microfinance Institutions in Kenya. Journal of Economics and Financial Analysis, 2, 23-39.

McKibbin, W. J., \& Sidorenko, A. A. (2006). Global Macroeconomic Consequences of Pandemic Influenza. Sydney: The Crawford School of Public Policy, Centre for Applied Macroeconomic Analysis

McLeod, S. A. (2019). What a p-Value Tells You about Statistical Significance. Simply Psychology. https://www.simplypsychology.org/p-value.html

MFTransparency (2011). Country Survey: Malawi (April, pp. 1-15). http://www.mftransparency.org/wp-content/uploads/2012/05/MFT-RPT-103-EN-Cou ntry-Survey-Malawi.pdf

Mirpourian, S., Caragliu, A., Di Maio, G., Landoni, P., \& Rusinà, E. (2016). Determinants of Loan Repayment Performance among Borrowers of Microfinance Institutions: Evidence from India. World Development Perspectives, 1, 49-52. https://doi.org/10.1016/j.wdp.2016.06.002

Muhammad, S. D. (2010). Microfinance Challenges and Opportunities in Pakistan. European Journal of Social Sciences, 14, 88-97.

Munthali, G. N. C., \& Wu, X. L. (2020a). COVID-19 Lockdown Measures on Least Developing Economies in Africa-A Case of Malawi Economy. Technium Social Sciences Journal, 7, 295-301. https://doi.org/10.47577/tssj.v7i1.394

Munthali, G. N. C., \& Wu, X. L. (2020b). Covid-19 Outbreak on Malawi Perspective. 
Electronic Journal of General Medicine, 17, Article No. em210.

https://doi.org/10.29333/ejgm/7871

Mutambanadzo, T., Bhiri, T., \& Makunike, S. (2013). An Analysis Challenges Faced by Zimbabwean Micro Finance Institutions in Providing Financial Services to the Poor and Informal Sector in the Dollarised Regime. Global Institute of Research and Education, 2, 154-159.

Ousoombangi, D. (2018). Challenges That Face the Operations of Microfinance Institutions in Kenya: A Case Study of Microfinance Institutions in Nairobi County. International Journal of Business and Management Invention (IJBMI), 7, 69-77.

Registrar, T. (2019). The Registrar of Financial Institutions Annual Report.

Sataloff, R. T., Johns, M. M., \& Kost, K. M. (n.d.). Micro Finance Handbook.

Schicks, J. (2014). Over-Indebtedness in Microfinance-An Empirical Analysis of Related Factors on the Borrower Level. World Development, 54, 301-324.

https://doi.org/10.1016/j.worlddev.2013.08.009

Sekabira, H., Economics, N. R., Economics, N. R., \& Sciences, A. (2013). Capital Structure and Its Role on Performance of Microfinance Institutions: The Ugandan Case. Sustainable Agriculture Research, 2, 86-100. https://doi.org/10.5539/sar.v2n3p86

Seo, M.-G., Bartunek, J. M., \& Barrett, L. F. (2010). The Role of Affective Experience in Work Motivation: Test of a Conceptual Model. Journal of Organizational Behavior, 31, 951-968. https://doi.org/10.1002/job.655

Song, G., Liu, L., He, S., Cai, L., \& Xu, C. (2020). Safety Perceptions among African Migrants in Guangzhou and Foshan, China. Cities, 99, 102624.

https://doi.org/10.1016/j.cities.2020.102624

Sun, S., Nabunya, P., Byansi, W., Sensoy Bahar, O., Damulira, C., Neilands, T. B. et al. (2020). Access and Utilization of Financial Services among Poor HIV-Impacted Children and Families in Uganda. Children and Youth Services Review, 109, 104730. https://doi.org/10.1016/j.childyouth.2019.104730

Thesis, E. D. (2008). Microfinance and Poverty Alleviation: A Case of Obazu Progressive Women Association. Nnenna Christiana Irobi Supervisors: Linley Chiwona-Karltun (PhD) Prof. Bo Ohlmer, Thesis No. 533.

Type, I., \& Felix, K. (2021). This Thesis Is Hosted in Bradford Scholars-The University of Bradford Open Access. University of Bradford eThesis.

Umamuefula, S., Onyeagocha, O., Angus, S., Dixie, N., \& Chukwuemeka, E. (2012). Determinants of Repayment of Loan Beneficiaries of Micro Finance Institutions in Southeast States of Nigeria. International Journal of Agricultural Management and Development (IJAMAD), 2, 167-175.

Wangechi, G. B. (2009). Factors Influencing Sustainability of Microfinance Institutions in Kenya (pp. 519-537). MBA Thesis, Nairobi: University of Nairobi.

Wasiaturrahma, Ajija, S. R., Sukmana, R., Sari, T. N., \& Hudaifah, A. (2020). Breadth and Depth Outreach of Islamic Cooperatives: Do Size, Non-Performing Finance, and Grant Matter? Heliyon, 6, e04472. https://doi.org/10.1016/j.heliyon.2020.e04472

Wellalage, N. H., \& Locke, S. M. (2013). Corporate Governance, Board Diversity and Firm Financial Performance: New Evidence from Sri Lanka. International Journal of Business Governance and Ethics (IJBGE), 8, No. 2. https://doi.org/10.1504/IJBGE.2013.054416

Zeller, M., \& Sharma, M. (2000). Many Borrow, More Save, and All Insure: Implications for Food and Micro-Finance Policy. Food Policy, 25, 143-167.

https://doi.org/10.1016/S0306-9192(99)00065-2 